\title{
PENGARUH MODEL PEMBELAJARAN BERBASIS MASALAH TERHADAP HASIL BELAJAR SISWA PADA MATERI POKOK LISTRIK DINAMIS KELAS X SEMESTER II SMA NEGERI 1 SUMBUL T.P 2014/2015
}

\author{
Yunita Welda S Sipayung dan Juniar Hutahaean \\ Jurusan Fisika FMIPA Universitas Negeri Medan \\ Jalan Willem Iskandar Pasar V Medan, Sumatera Utara \\ junhut@gmail.com
}

\begin{abstract}
ABSTRAK
Penelitian ini bertujuan untuk mengetahui adanya pengaruh penerapan model pembelajaran berbasis masalah terhadap hasil belajar siswa pada materi pokok listrik dinamis di kelas X semester II SMA Negeri 1 Sumbul T.P. 2014/2015. Jenis penelitian ini adalah quasi experiment dengan two group pre-test and post-test design. Pengambilan sampel dilakukan dengan cara cluster random sampling dengan mengambil dua kelas dari lima kelas yaitu kelas X-6 sebagai kelas eksperimen dan kelas $\mathrm{X}-2$ sebagai kelas kontrol yang masing-masing berjumlah 40 orang. Instrumen yang digunakan berupa tes hasil belajar dalam ranah kognitif berbentuk uraian yang terdiri dari 10 soal essay yang sudah dinyatakan valid oleh para ahli dan lembar observasi untuk mengukur aktivitas. Hasil penilaian di kelas eksperimen menunjukkan aktivitas dengan kategori aktif Untuk menguji hipotesis digunakan uji beda (uji t), setelah uji prasayarat normalitas dan homogenitas. Nilai rata-rata kelas eksperimen 26,44 dan nilai rata-rata kelas kontrol 27,70. Setelah pembelajaran selesai diberikan postes dengan hasil rata-rata kelas eksperimen 60,01 dan kelas kontrol 52,05. Berdasarkan hasil uji t diperoleh bahwa ada pengaruh penerapan model pembelajaran berbasis masalah terhadap hasil belajar siswa pada materi pokok listrik dinamis di kelas X semester II SMA Negeri 1 Sumbul .
\end{abstract}

Kata kunci : model berbasis masalah, hasil belajar dan aktivitas.

\begin{abstract}
This research is used to observe the effect of problem based learning model to increase students learning outcomes in dynamic electricity matter in class-x semester II SMA Negeri 1 Sumbul A.Y.2014/2015. This type of this research is quasi experiment with two group pre-test and post-test design. The sample was taken with cluster random sampling by take two class from five class that is $X-6$ as experimental class and $X-2$ as control class, every class consist of 40 students. The instrument that used is learning outcomes test in cognitive aspect in form essay test that consist of 10 essay test that had been valid by validator and observation sheet to measure activity of student. The result of this reserach in experimental class show that the activity in active cathegory. To measured the hypotesys test is udsed different test ( $t$-test), after normality test and homogeneity test .The average value in experimental class was 26.44 and in control class was 27.70. After the learning process had been finished the class was given with post-test with the average value in experimental class was 60.01 and in control class was 52.05. Based on the result of $t$-test, that is show that there was effect problem
\end{abstract}


based learning model to increase student learning outcomes in dynamic electricity matter in class- X semester II SMA Negeri 1 sumbul .

Keyword: Problem based learning , learning outcomes and activity

\section{PENDAHULUAN}

Fisika salah satu cabang IPA merupakan suatu ilmu pengetahuan yang mempelajari gejala-gejala alam dan interaksi di dalamnya. Pelajaran fisika lebih menekankan pada pemberian langsung untuk meningkatkan kompetensi agar siswa mampu berpikir kritis dan sistematis dalam memahami konsep fisika, sehingga siswa memperoleh pemahaman yang benar tentang fisika. Pemahaman yang benar akan pelajaran fisika akan sangat berpengaruh terhadap hasil belajar siswa. Akan tetapi, pada kenyataannya hasil belajar peserta didik pada pembelajaran fisika masih rendah.

Kesulitan belajar siswa akan sangat mempengaruhi hasil belajar siswa, baik karena faktor internal maupun eksternal yang di hadapi oleh siswa. Oleh karena itu siswa harus mampu menghadapi kesulitan dari faktor yang mempengaruhi kesulitan tersebut sehingga tidak berpengaruh terhadap hasil belajar siswa. Proses pembelajaran yang monoton, juga menjadi salah satu masalah pembelajaran yang sering ditemui di sekolah yang mana pengajaran yang dilakukan oleh guru berjalan pada satu orientasi saja yaitu hanya mengutamakan penguasaan pada mata pelajaran saja. Siswa dapat dan dikatakan menguasai suatu pembahasan mata pelajaran dengan hafalan-hafalan sehingga siswa kurang menghayati dan menjiwai pembahasaan yang diajarkan.

Berdasarkan hasil observasi yang dilakukan oleh peneliti di sekolah SMA Negeri 1 Sumbul, pelajaran fisika sampai saat ini masih dianggap sebagai pelajaran yang sulit dan membosankan serta menempati posisi terakhir sebagai pilihan mata pelajaran yang disukai oleh siswa . Dari hasil angket yang disebarkan kepada 40 orang siswa, $70 \%$ (28 orang siswa) berpendapat fisika merupakan pelajaran yang sulit dipahami, kurang menarik, dan membosankan, $20 \%$ (8 orang siswa) berpendapat fisika biasa - biasa saja, dan hanya $10 \%$ (4 orang siswa) yang berpendapat fisika menyenangkan dan menantang.

Penyebab rendahnya hasil belajar ini, salah satunya adalah proses pembelajaran yang tidak berpihak pada siswa. Dalam pembelajaran siswa bersifat hanya pendengar saja dan guru yang bersifat dominan (teacher centered). Dominasi guru dalam pembelajaran ini menyebabkan siswa lebih banyak menunggu sajian dari guru daripada menemukan sendiri pengetahuan, keterampilan, dan sikap yang dibutuhkan. Ini didukung dari hasil wawancara kepada salah seorang guru fisika, diketahui bahwa nilai rata-rata ujian fisika siswa kelas $X$ masih rendah jika dilihat dari nilai Kriteria Ketuntasan Minimal (KKM) yaitu 73. Pada T.P. $2013 / 2014$ rata-rata nilainya 59 dan pada T.P. 2014/2015 rata-rata nilainya 64 . Data ini menunjukkan bahwa nilai rata-rata ujian fisika kelas X SMA Negeri 1 Sumbul untuk kedua Tahun Pelajaran tersebut masih tergolong rendah.

Berdasarkan hasil wawancara yang dilakukan peneliti dengan beberapa siswa di sekolah tersebut mengatakan bahwa pada proses pembelajaran siswa jarang melakukan percobaan atau praktikum. Metode mengajar yang sering dilakukan adalah ceramah, mencatat, dan mengerjakan soal atau penugasan. Hal tersebut menunjukkan aktivitas siswa kurang dan menyebabkan siswa menjadi tidak aktif dan kreatif. Jika aktivitas siswa kurang maka hal ini juga berpengaruh pada rendahnya hasil belajar siswa.

Banyak cara yang dapat dilakukan untuk mengatasi masalah dalam proses 
pembelajaran, salah satunya yaitu dengan memilih model pembelajaran yang dapat memacu siswa lebih aktif dalam mengikuti poses belajar mengajar. Salah satu upaya untuk meningkatkan hasil belajar siswa adalah dengan menggunakan model pembelajaran berbasis masalah (problem based learning-PBL) yaitu, suatu pendekatan pembelajaran di mana siswa mengerjakan permasalahan yang otentik dengan maksud untuk menyusun pengetahuan mereka sendiri, mengembangkan inkuiri dan ketrampilan berpikir tingkat lebih tinggi, mengembangkan kemandirian dan percaya diri. Arends (2012) menyatakan bahwa model problem based learning merupakan suatu pendekatan pembelajaran dimana siswa mengerjakan permasalahan yang autentik dengan maksud untuk menyusun pengetahuan mereka sendiri, mengembangkan inkuiri dan keterampilan berpikir tingkat lebih tinggi, mengembangkan kemandirian dan percaya diri.

Model PBL dapat meningkatkan hasil belajar, hal ini didukung oleh penelitian Setiawan, dkk., (2012) dimana rata-rata hasil belajar siswa kelas dengan menerapkan model PBL sebesar 73,77 dan kelas konvensional sebesar 62,76; Rusnayati dan Prima (2011) dengan hasil belajar rata-rata siswa kelas eksperimen yangmenerapkan model PBL 88,0 dan kelas kontrol sebesar 79,8. Para peneliti tersebut menyimpulkan bahwa model pembelajaran ini dapat meningkatkan hasil belajar fisika siswa secara signifikan, namun penelitianpenelitian ini memiliki kelemahan dalam pengalokasian waktu setiap tahapan pembelajaran berbasis masalah yang kurang efisien, dan tidak melakukan pengamatan terhadap aktivitas siswa selama pembelajaran berlangsung.

Adapin upaya yang dilakukan peneliti untuk mengatasi kelemahan di atas adalah dengan melakukan observasi terhadap aktivitas siswa selama pembelajaran berbasis masalah berlangsung. Selain itu, peneliti akan memberikan dan membimbing siswa dalam mengerjakan Lembar Kerja Siswa (LKS) yang relevan dengan kehidupan sehari-hari, dan membuat rencana pelaksanaan pembelajaran (RPP) dengan pengalokasian waktu seefisien mungkin sehingga diharapkan hasil belajar siswa akan lebih baik.

Adapun tujuan penelitian adalah untuk menlihat pengaruh model pembelajaran berbasis masalah terhadap hasil belajar siswa pada materi listrik dinamis di kelas x SMA Negeri 1 Sumbul T.P 2014/2015.

\section{METODE PENELITIAN Tempat Penelitian}

Penelitian ini dilaksanakan di SMA Negeri 1 Sumbul, Sumatera Utara. Populasi dalam penelitian ini adalah seluruh siswa kelas X SMA Negeri 1 Sumbul T.P 2014/2015 yang terdiri dari 7 kelas yang berjumlah 280 orang.

Jenis penelitian ini adalah quasi experiment. Sampel penelitian dipilih dengan cluster random sampling, kelas X-6 sebagai kelas eksperimen yang menerapkan model problem based learning dan kelas X2 sebagai kelas kontrol yang menerapkan pembelajaran konvensional. Desain penelitian yang digunakan adalah control group pretest-posttest yang ditunjukkan oleh Tabel 1.

Tabel 1. Control Group Pretest-Posttest Design (Arikunto, 2012)

\begin{tabular}{|l|c|c|c|}
\hline \multicolumn{1}{|c|}{ Kelas } & Pretes & $\begin{array}{c}\text { Perla } \\
\text { kuan }\end{array}$ & Postes \\
\hline Eksperimen & $O_{1}$ & $X_{1}$ & $O_{2}$ \\
\hline Kontrol & $O_{1}$ & $X_{2}$ & $O_{2}$ \\
\hline
\end{tabular}

Keterangan:

$O_{1}=$ pretes

$X_{1}=$ model problem based learning

$\mathrm{O}_{2}=$ postes

$X_{2}=$ pembelajaran konvensional

Tes yang digunakan untuk memperoleh data hasil belajar siswa sebelum dan sesudah pembelajaran berupa tes uraian sebanyak 10 soal. Sebelum dilakukan penelitian, tes yang telah disusun 
terlebih dahulu diuji validitasnya. Jenis validitas yang digunakan adalah validitas isi oleh validator ahli dan validitas ramalan, meliputi tingkat kevalidan dan tingkat realibilitas soal, yang dilaksanakan dengan mengujikan soal yang telah dibuat kepada siswa sekolah lain yang sudah pernah mempelajari materi tersebut. Observasi dilakukan oleh dua orang observer dengan menggunakan lembar observasi.

Teknik analisis yang digunakan untuk menentukan pengaruh model problem based learning terhadap hasil belajar siswa adalah melakukan uji hipotesis dengan menggunakan uji beda (uji t) dengan syarat data harus berdistribusi normal dan bersifat homogen (Sudjana, 2005). Teknik analisis ini dilakukan pada data tes hasil belajar yang diperoleh yaitu data pretes dan postes.

Apabila hasil pretes kedua kelas memiliki kesamaan rata-rata, berarti kemampuan awal kelas eksperimen sama dengan kemampuan awal siswa pada kelas kontrol. Apabila hasil postes kelas eksperimen yang menerapkan model problem based learning lebih tinggi dari kelas kontrol dengan pembelajaran konvensional, berarti ada perbedaan hasil belajar kognitif yang signifikan akibat penerapan model problem based learning, sehingga dapat disimpulkan bahwa model ini ada pengaruhnya terhadap hasil belajar siswa.

\section{HASIL DAN PEMBAHASAN Hasil Penelitian}

Data yang dideskripsikan pada penelitian ini meliputi data hasil belajar fisika pada materi listrik dinamis yang diberikan perlakuan berbeda yaitu 1 kelas dengan model pembelajaran berbasis masalah dan 1 kelas lagi dengan menggunakan pembelajaran konvensional.

Pretes (tes awal) dilakukan untuk mengetahui kemampuan awal siswa. Setelah pretes, memberikan perlakuan dengan menerapkan model pembelajaran berbasis masalah pada kelas eksperimen dan pembelajaran konvensional pada kelas kontrol kemudian melakkan postes (tes akhir).

Nilai rata-rata pretes untuk kelas eksperimen dan kontrol secara berurutan adalah 26,44 dan 27,70. Data pretes berdistribusi normal dan homogen, maka dilakukan uji hipotesis data pretes menggunakan uji $t$. Berdasarkan hasil perhitungan uji $t$, maka disimpulkan bahwa siswa kelas eksperimen dengan siswa kelas kontrol mempunyai kemampuan awal yang sama.

Nilai rata-rata postes untuk kelas eksperimen dan kontrol secara berurutan adalah 60,01 dan 52,05. Berdasarkan hasil perhitungan uji $t$, disimpulkan bahwa ada pengaruh model problem based learning yang signifikan terhadap hasil belajar siswa pada materi Listrik Dinamis kelas X SMA Negeri 1 Sumbul. Nilai rata-rata pretes dan postes untuk kelas eksperimen dan kelas kontrol ditunjukkan pada Gambar 1.

Gambar 1. Nilai rata-rata pretes dan postes untuk kedua kelas

Selama proses pembelajaran, pengamatan aktivitas siswa dilakukan tiga kali pertemuan setelah melakukan pretes. Observasi aktivitas ini dilakukan hanya di kelas eksperimen saja. Aspek afektif yang dinilai adalah visual, oral, listening, writing, motor, mental, dan emotional dalam proses pembelajaran. Hasil observasi aktivitas kelas eksperimen ditunjukkan pada Gambar 2. Berdasarkan Gambar 2, aktivitas siswa meningkat di setiap pertemuan.

Gambar 2. Aktivitas Siswa tiap Pertemuan

\section{Pembahasan}

Penelitian diawali dengan
memberikan pretes terhadap kelas eksperimen dan kelas kontrol. Hasil pretes kelas eksperimen memperoleh nilai ratarata 26,44 dan nilai rata-rata pretes kelas kontrol adalah 27,70. Hasil tersebut menyatakan bahwa kemampuan awal siswa 
pada kelas eksperimen tidak jauh berbeda dengan kemampuan awal kelas kontrol sebelum diberi penerapan. Setelah diberi penerapan yang berbeda yaitu pada kelas eksperimen diberi penerapan menggunakan model pembelajaran berbasis masalah sedangkan kelas kontrol diberi dengan menggunakan pembelajaran konvensional. Setelah diberikan penerapan kedua kelas diberikan tes akhir (postes) untuk melihat adanya perbedaan akibat diberikan perlakuan pembelajaran yang berbeda. Hal ini dapat dilihat dari hasil rata-rata postes kelas eksperimen, memperoleh nilai ratarata 60,01 dengan standar deviasi 156,23 sedangkan di kelas kontrol 52.

Hasil uji hipotesis untuk postes menggunakan uji $\mathrm{t}$ pada taraf signifikan $=$ 0,05 diperoleh $t_{\text {hitung }}>t_{\text {tabel }}(2,992>1,994)$ yang berarti bahwa ada perbedaan hasil belajar siswa yang menggunakan model pembelajaran berbasis masalah dengan pembelajaran konvensional.

Hasil belajar siswa kelas eksperimen dikatakan belum tuntas. Dimana menurut Pujiati (2008:9) ketuntasan belajar merupakan pencapaian hasil belajar yang ditetapkan dengan ukuran atau tingkat pencapaian kompetensi yang memadai dan dapat dipertanggungjawabkan sebagai prasyarat penguasaan kompetensi lebih lanjut. Pada tingkat satuan pendidikan pembelajaran dikatakan berhasil jika $75 \%$ dari seluruh jumlah siswa mencapai nilai ketuntasan. Spesifikasi tes hasil belajar dimulai dari $\mathrm{C}_{2}-\mathrm{C}_{6}$. Pada saat dilakukan pretes di dua kelas eksperimen dan kontrol ternyata data yang diperoleh tidak ada yang tuntas untuk setiap nomor soalnya karena keseluruhan dari nilai siswa untuk setiap kategori dan nomor di bawah $75 \%$. Kemudian saat dilakukan posttest soal no 1 dan 3 kategori $\mathrm{C} 4$ yang dapat memenuhi nilai di atas $75 \%$ yaitu sebesar $85 \%$, untuk yang lain belum dapat mencapai nilai $75 \%$. Secara keseluruhan baik data pretes maupun postes dikatakan tidak berhasil atau tidak tuntas. Ketidak-berhasilan ini juga disebabkan oleh beberapa faktor yang dialami peneliti di kelas yaitu situasi kelas yang ribut, ketersediaan alat dan bahan yang terbatas, dan keterbatasan waktu saat pembelajaran sehingga proses pembelajaran kurang maksimal.

Saat penelitian, siswa dibagi kedalam 4 kelompok, berbeda dengan perencanaan sebelumya karena keterbatasan alat dan bahan . Pada pertemuan pertama, nilai rata-rata LKS siswa masih tergolong cukup rendah yaitu sebesar 33,5 dengan nilai kelompok I 40, kelompok II 50, kelompok III 20 dan kelompok IV 24. Pada hari pertama peneliti mengalami kendala yang cukup banyak. Misalnya dalam pembagian kelompok. Siswa masih memilih-milih teman satu kelomponya dan menyebabkan suasana kelas menjadi ribut karena siswa kesusahan untuk memindahmindahkan tempat duduknya. Selain itu pada hari pertama ini, siswa masih belum dapat langsung mengerjakan LKS karena mereka belum mengerti sama sekali dengan model pembelajaran berbasis masalah. Alasan lain juga karena peneliti harus menjelaskan terlebih dahulu hal-hal apa yang harus dilakukan termasuk tahap-tahap penyelidikan juga pengenalan alat dan bahan. Siswa masih belum begitu paham menggunakan multimeter, makan peneliti harus menjelaskan dulu cara penggunaanya kepada siswa. Peneliti juga menuntun siswa untuk merumuskan masalah dan membuat hipotesis. Kendala lain adalah karena kertebatasan peneliti menghadapi siswa yang banyak begutu banyak jumlahnya dan guru mata pelajaran pun tidak ikit membantu akibatnya proses-proses tersebut cukup memakan waktu sehingga siswa belum dapat mengerjakan LKS secara maksimal.

Pada pertemuan kedua, peneliti melakukan model yang sama lagi dan membagikan LKS. Pada pertemuan ini terlihat nilai ratarata LKS siswa mengalami peningkatan menjadi 54. Berbeda dengan pertemuan pertama, peneliti langsung yang membagi kelompok siswa agar tidak terjadi lagi keributan seperti pada pertemuan sebelumnya. Selain itu peneliti juga menjelaskan tahap-tahap penyelidikan 
langsung di depan kelas agar keseluhan siswa dapat mendengarnya dan tidak banyak bertanya lagi dan menunggu peneliti datang ke meja kelompoknya. Pada pertemuan ini, kendala yang dihadapi peneliti adalah siswa yang masih takuttakut untuk bertanya tentang tahap-tahap yang belum dimengerti. Akibatnya siswasiswa belum dapat menyelesaikan LKS dengan baik.

Pertemuan ketiga, terlihat siswa yang mulai senang dengan praktikum yang dilaksanakan. Terlihat bagaimana siswa tidak bingung lagi dalam merumuskan masalah serta membuat hipotesis. Siswa juga langsung duduk sesuai dengan kelompok yang sudah ditentukan oleh peneliti sehingga kelas tidak ribut lagi. Selain itu siswa juga sudah berani bertanya kepada peneliti dan pada pertemuan ini, siswa sempat dibantu oleh guru mata pelajarannya. Sehingga pembelajaran dapat berlangsung dengan baik. Ini bisa dibuktikan dengan nilai LKS siswa yang juga mengalami peningkatan yaitu sebesar 72,5 .

Berdasarkan kendala tersebut disarankan kepada peneliti selanjutnya agar membuat perencanaan dengan sejelasjelasnya, benar-benar mempersiapkan perangkat yang akan digunakan, dapat mengkondusifkan kelas pada saat pembelajaran berlangsung dengan cara lebih tegas dalam mengarahkan siswa, dan menggunakan model pembelajaran berbasis masalah guna menambah daya ingat siswa terhadap materi yang diajarkan, serta karena jumlah siswa dan aktivitas yang akan diobservasi banyak maka supaya efektif sebaiknya diperlukan satu observer setiap kelompok belajar yang juga mengerti akan materi yang kita ajarkan. Peneliti juga menyarankan agar guru sebaiknya memperkenalkan siswa dengan alat dan bahan praktikum agar siswa tidak canggung dan bingung dalam melakukan eksperimen.

Peningkatan hasil belajar menggunakan model pembelajaran berbasis masalah lebih baik disebabkan model pembelajaran ini lebih berpusat pada siswa sehingga siswa lebih aktif untuk mengkonstruksi langsung pengetahuan melalui setiap kegiatan yang telah dirancang pada fase model pembelajaran berbasis masalah. Pada kelas kontrol pembelajaran berpusat pada guru, sedangkan siswa hanya mendengar saja, tidak terlalu banyak melibatkan siswa dalam bekerja. Selain itu, model pembelajaran berbasis masalah ini mempunyai keunggulan dibandingkan dengan pembelajaran konvensional antara lain: semua anggota kelompok wajib mendapat tugas. Hal ini menyebabkan setiap anggota kelompok aktif, ada interaksi antara siswa dengan siswa dan siswa dengan guru, siswa dapat menukar ide satu sama lain, siswa terlatih untuk berpikir kritis dan terampil untuk memecahkan masalah dalam bidang studi fisika.

Model pembelajaran berbasis masalah dapat memberikan kesempatan pada siswa bereksplorasi mengumpulkan dan menganalisis data untuk memecahkan masalah sehingga siswa memiliki rasa ingin tahu dalam menemukan alternatif pemecahan masalah, menjelaskan materimateri yang dimulai dari pusat permasalahan yang terjadi dalam lingkungan siswa. Maka dalam hal ini siswa aktif dan antusius untuk bekerjasama dengan satu kelompok menyelesaikan masalah yang telah diberikan oleh peneliti. Siswa juga tertarik dan aktif saat berdiskusi dan mengeluarkan pendapat saat diadakan diskusikan antar kelompok. Pada tahap orientasi siswa pada masalah (pertama), peneliti memotivasi siswa dengan memberikan tujuan pembelajaran yang akan dicapai oleh siswa dan pada tahap ini peneliti memberikan masalah kepada siswa dengan memberikan pertanyaan sederhana yang berbeda di dalam kehidupan seharihari siswa. Pada tahap ini siswa akan berusaha menemukan jawaban dari permasalahan dan membuat hipotesis sendiri. Pada tahap mengorganisasi siswa untuk belajar (kedua), peneliti memberikan materi pelajaran kemudian membentuk kelompok-kelompok belajar dan melakukan 
percobaan (eksperimen). Pada tahap penyelidikan individual maupun kelompok (ketiga), peneliti membimbing setiap siswa untuk mengumpulkan informasi untuk memecahkan masalah melakukan percobaan (eksperimen) sesuai dengan pada LKS yang telah diberikan oleh peneliti. Pada tahap mengembangkan dan menyajikan hasil karya (keempat) peneliti membantu setiap kelompok menyelesaikan dan menjaa semua permasalahan yang ada serta mempersentasikan hasil diskusi kelompok yang sudah disiapkan, kemudian kelompok lain diberi kesempatan memberikan pendapat atau masukan. Pada tahap menganalisis dan mengevaluasi proses mengatasi masalah (kelima) peneliti membantu siswa dalam mengkaji ulang permasalalahan sesuai dengan tujuan pembelajaran dan memberikan penguatan pada pemecahan masalah dan membuat tes evaluasi untuk mengetahui pemahaman siswa.

Pelaksanakan kelima fase inilah yang menyebabkan siswa lebih aktif terutama belajar dalam tim dan diskusi, dalam hal ini masing-masing siswa berusaha dan bertanggung-jawab secara individu untuk melakukan yang terbaik sebagai kesuksesan kelompoknya, sehingga hasil belajar siswa kelas eksperimen lebih tinggi dibandingkan kelas kontrol.

Penelitian ini juga menilai aktivitas siswa pada kelas eksperimen selama kegiatan belajar mengajar berlangsung. Berdasarkan hasil observasi aktivitas siswa pada setiap pertemuan mengalami peningkatan. Pada pertemuan I rata-rata skor aktivitas siswa sebesar 68,01 yang termasuk ke dalam kategori cukup aktif. Hal ini terajadi karena siswa belum terbiasa dengan model pembelajaran berbasis masalah. Jadi pada saat pembelajaran siswa masih bingung dan masih takut-takut untuk bertanya hal-hal yang kurang dimengerti. Pada pertemuan ini, siswa juga masih kurang mampu membuat kesimpulan dalam pembelajaran. Pada pertemuan II rata-rata skor aktivitas siswa meningkat menjadi 72,79 yang masih termasuk kategori aktif.
Aktivitas meningkat karena pada pertemuan kedua ini siswa sudah mulai terbiasa dengan model pembelajaran berbasis masalah. Selain itu juga siswa sudah mau bertanya dan mulai mengajukan pendapatnya atau sudah mau berbicara di dalam kelas. Pada pertemuan III rata-rata skor siswa menjadi 77,62 yang termasuk kategori aktif, semakin terlihat bahwa aktivitas siswa terus meningkat. Peningkatan ini terjadi karena siswa semakin berani untuk bertanya, menjawab pertanyaan dan mengeluarkan pendapat bekerja sama dengan baik dalam kelompok dan saling bertanggung jawab dengan tugas masing-masing.

Berdasarkan hasil penelitian, model pembelajaran pembelajaran berbasis masalah dapat memberikan dampak positif terhadap siswa, model pembelajaran ini mampu memberikan kesempatan bagi siswa untuk lebih aktif dalam proses pembelajaran. Melalui penerapan model pembelajaran berbasis masalah, siswa memperoleh pengetahuan baru yang dikaitkan dengan pengetahuan yang telah ada pada pembelajaran. Siswa terlibat dalam kelompok belajar agar siswa mudah berdiskusi untuk memecahkan persoalan yang ada.

$\begin{array}{ccr}\text { Sesuai } & \begin{array}{c}\text { dengan } \\ \text { dengan }\end{array} & \begin{array}{r}\text { penelitian } \\ \text { menggunakan }\end{array} \\ \text { sebelumnya } & \begin{array}{c}\text { dengenalaran } \\ \text { berbasis }\end{array} & \text { masalah yang }\end{array}$ dilakukan oleh Setiawan (2012) dengan hasil belajar rata-rata siswa kelas eksperimen sebesar 73,77 dan kelas kontrol sebesar 62,76; Rusnayati dan Prima (2011) dengan hasil belajar rata-rata siswa kelas eksperimen 88,0 dan kelas kontrol sebesar 79,8; Suhanda, dkk., (2014) dengan hasil belajar rata-rata kelas eksperimen 75,13 dan kelas kontrol sebesar 66,19. Dalam setiap hasil yang ada jelas terlihat perbedaan nilai antara kelas ekperimen atau dengan menggunakan model pembelajaran masalah atau kelas kontrol dengan menggunakan pembelajaran konvesional.

\section{KESIMPULAN DAN SARAN}




\section{Kesimpulan}

Berdasarkan hasil penelitian yang diperoleh maka dapat disimpulkan bahwa: (1) hasil belajar siswa kelas eksperimen dengan menerapkan model pembelajaran berbasis masalah dengan kategori cukup baik. (2) Ada perbedaan akibat pengaruh model pembelajaran berbasis masalah terhadap hasil belajar siswa. (3) Rata-rata aktivitas belajar siswa selama proses pembelajaran termasuk dalam kategori aktif.

\section{Saran}

Berdasarkan hasil penelitian dan kesimpulan di atas, maka sebagai tindak lanjut dari penelitian ini disarankan beberapa hal sebagai berikut: (1) Untuk penelitian selanjutnya hendaknya menambah jumlah observer, agar lebih mengoptimalkan pengelolaan kelas khususnya pada saat diskusi berlangsung agar tidak terjadi kegaduhan-kegaduhan di dalam kelas dan alangkah baiknya apabila observernya paham dengan materi yang kita jelaskan agar dapat membantu selama proses pembelajaran. (2) Mempersiapkan dan melengkapi ketersediaan alat dan bahan yang dibutuhkan .

\section{DAFTAR PUSTAKA}

Arends, R., (2012), Learning to Teach Ninth Edition, Yogyakarta: Pustaka Pelajar.
Arikunto, S., (2012), Dasar-dasar Evaluasi Pendidikan, Jakarta: Bumi Aksara.

Pujiati, I., (2008), Peningkatan Motivasi dan Ketuntasan Belajar Matematika Melalui Pembelajaran Kooperatif Tipe STAD, Jurnal Ilmiah Kependidikan, (1) (1): 1-20

Rusnayati dan Prima, E. C., (2011), Penerapan Model Pembelajaran Problem Based Learning Dengan Pendekatan Inkuiri Untuk Meningkatkan Keterampilan Proses Sains Dan Penguasaan Konsep Elastisitas Pada Siswa Sma, Skripsi, FMIPA Universitas Negeri Yogyakarta

Setiawan, G. C., Suprihati, T dan Astutik, S., (2012), Penerapan Model Pembelajaran Problem Based Learning (PBL) disertai Media Komputer Makromedia Flash, Jurnal Pembelajaran Fisika, (1) (3) :291293

Sudjana, N., (2005), Metode Statistik, Bandung: Tarsito.

Suhanda, Asmendri dan Khaira, K., (2014), Penerapan Model Pembelajaran Berbasis Masalah dan Tutor Teman Sebaya terhadap Hasil Belajar Fisika Kelas VII MTSN Kota Solok V, Jurnal Pendidikan FMIPA, (41) (11): $74-76$ 